\title{
Radiological Analysis of Proximal Humerus Restoration and Functional Outcome in Shoulder Hemiarthroplasty
}

\section{Omuz Hemiartroplastisinde Proksimal Humerus Restorasyonunun Radyolojik Analizi ve Fonksiyonel Sonuçlar}

\author{
Onur GÜRSAN ${ }^{1}$, Mustafa ÖZKAN ${ }^{1}$, Ahmet Emrah AÇAN ${ }^{2}$ \\ ${ }^{1}$ Dokuz Eylül University, Faculty of Medicine, Department of Orthopedics and Traumatology, Izmir \\ ${ }^{2}$ Balıkesir University, Faculty of Medicine, Department of Orthopedics and Traumatology, Balıkesir
}

\begin{abstract}
In shoulder hemiarthroplasty, the glenohumeral offset, subacromial gap, vertical and horizontal measurements of tuberosities, and stage of fatty infiltration are some of the radiological parameters that evaluate the restoration of proximal humerus. This study was designed to determine which radiological parameters are more compatible with functional results after hemiarthroplasty. Twenty-five patients, who were treated between 2002 and 2010 for proximal humerus fractures with hemiarthroplasty and had post-operative computed tomography (CT) scans, were evaluated. The final position of the prosthetic head, tuberculum restoration, and fatty degeneration of the supraspinatus muscle were analysed radiologically. The American Shoulder and Elbow Society (ASES) score, Constant-Murley score, Disabilities of the Arm, Shoulder, and Hand (DASH) index score were used to determine functional performance. The mean ASES, Constant-Murley, and DASH index scores of patients aged 52 to 84 years were 70,66 , and 23 , respectively. The patient group with a normal retroverted prothesis had higher Constant-Murley and lower DASH index scores $(\mathrm{p}<0.05)$. The group with 0 to $5 \mathrm{~mm}$ horizontal malpositioning in CT scans had better clinical outcomes $(\mathrm{p}<0.05)$. Better clinical outcomes were noted in the stage 0 fatty infiltration group $(\mathrm{p}<0.05)$. Hemiarthroplasty remains an important treatment option in proximal humerus fractures. In collaboration with achieving closer restoration to proximal humerus anatomy, the stage of fatty degeneration plays an important role in a successful functional result.

Keywords:
\end{abstract}

Keywords: Fatty Infiltration, Hemiarthroplasty, Proximal Humerus Fracture

\section{Introduction}

With the increase in the life expectancy of the population, the interest in osteoporosis-related fractures is developing. Proximal humerus fracture is one of the fractures associated with poor bone quality and constitutes $4 \%$ to $5 \%$ of fracture related applications. Approximately $80 \%$ can be treated conservatively (1-3). The surgical approach has a variety, ranging from percutaneous pinning, locked

\begin{tabular}{|c|c|}
\hline & ORCID No \\
\hline Onur GÜRSAN & $0000-0002-6356-3834$ \\
\hline Mustafa ÖZKAN & 0000-0003-1097-6608 \\
\hline Ahmet Emrah AÇAN & 0000-0001-7116-8773 \\
\hline Başvuru Tarihi / Received: & 16.10 .2020 \\
\hline Kabul Tarihi / Accepted : & 26.04 .2021 \\
\hline Adres / Correspondence : & Onur GÜRSAN \\
\hline $\begin{array}{l}\text { Dokuz Eylül University, } \\
\text { Orthopedics and Traumato }\end{array}$ & $\begin{array}{l}\text { aculty of Medicine, Department of } \\
\text { gy, Izmir }\end{array}$ \\
\hline e-posta / e-mail & onur_84_gursan@hotmail.com \\
\hline
\end{tabular}

Öz

Glenohumeral ofset, subakromiyal boşluk, tüberküllerinvertikal ve horizontal plandaki ölçümleri ve yağlinfiltrasyonun evreleri gibi radyolojik parametreler, omuz artroplastisinde, proksimalhumerusun restorasyonu incelenirken kullanılır.Bu çalışma, hemiartroplasti sonrası hangi radyolojik parametrelerin fonksiyonel sonuçlarla daha uyumlu olduğunu belirlemek için tasarlanmıştır. 2002-2010 yılları arasında proksimalhumerus kırıkları nedeniyle hemiartroplasti ile tedavi edilen ve postoperatif bilgisayarlı tomografi (BT) taramaları olan 25 hasta değerlendirildi. Protez başın son pozisyonu, tüberküllerin restorasyonu ve supraspinatus kasının yağlı infiltrasyonuradyolojik olarak analiz edildi. Fonksiyonel değerlendirmede, Amerikan Omuz ve Dirsek Topluluğu (ASES) Skoru, Constant-Murley skoru, DASH (kol,omuz ve elkisttllik indeksi) skoru kullanılmıştır. Yaş aralıkları 52-84 yaş arası değişen hastaların ortalama ASES, Constant-Murley ve DASH indeks skorları sirasiyla 70,66 ve 23 idi. Normal retroversiyona sahip protezi olan hasta grubu daha yüksek Constant-Murley ve daha düşük DASH indeks skorlarına sahipti $(\mathrm{p}<0.05)$. BT taramalarında 0 ila $5 \mathrm{~mm}$ horizontalmalpozisyonu bulunan grup daha iyi klinik sonuçlara sahipti $(p<0.05)$.Evre 0 yağlı infiltrasyonbulunan hasta grubunda daha iyi klinik sonuçlar not edildi $(\mathrm{p}<0.05)$. Hemiartroplasti, proksimalhumerus kırıklarında önemli bir tedavi seçeneği olmaya devam etmektedir. Proksimalhumerus anatomisine daha yakın restorasyon elde etmek ile birlikte yağlı infiltrasyonunevresi, başarılı bir fonksiyonel sonuçta önemli bir rol oynamaktadır.

Anahtar Kelimeler: Hemiartroplasti, Proksimal Humerus Kırığı, Yağlı İnfiltrasyon

nails, screw fixation, and plate osteosynthesis to shoulder hemiarthroplasty (4).

Hemiarthroplasty is indicated for four-part fractures: comminuted osteoporotic three-part proximal humerus fractures, fracture dislocations of the humeral head, head-splitting fractures, and impaction fractures involving at least $40 \%$ of the humeral articular surface $(5,6)$.

Although adequate pain relief has been consistently demonstrated after hemiarthroplasty, depending on the range of motion and muscle strength, functional outcomes are less predictable (7). Patient-related factors influencing the outcome include age, bone quality, comminuted fracture, and comorbidities (6). Technical factors associated with the outcome include the restoration of humeral head height, proper retroversion of the humeral component, secure fixation of tuberosities, and union of tuberosities to the humeral shaft. Tuberosity malpositioning has also been shown to adversely affect functional outcomes after hemiarthroplasty for 
three- and four-part proximal humerus fractures (79). Frankle et al. (10) examined the biomechanical consequences of tuberosity malreduction in the horizontal plane (malpositioning of the tuberosities located medially on the humeral shaft) and showed that tuberosity malpositioning leads to both abnormal glenohumeral kinematics and increased torque requirements for shoulder rotation. Fatty infiltration of the rotator cuff muscles is also an important prospective factor for functional outcomes (11). Greiner et al. (12) described that there was a clear tendency to lower clinical scores with increasing stages of fatty infiltration of the rotator cuff for each muscle. Moreover, tuberosity malpositioning correlated with fatty infiltration of the rotator cuff muscles. (12)

The restoration of the proximal humerus affects functional outcomes. Post-operative radiological parameters such as the lateral humeral offset, glenohumeral offset, stem height, retroversion, and position of tuberculum majus can demonstrate the success of restoration of the proximal humerus (13). In this retrospective study, we aimed to analyze the relationship between the intermediate-term functional outcomes of hemiarthroplasty and the post-operative radiological parameters which demonstrate the final position of tuberosities and fatty infiltration of the supraspinatus muscle.

\section{Material and Method}

Between 2002 and 2010, 131 patients, who underwent acute (under 21 days') hemiarthroplasty in DokuzEylül University Hospital (İzmir), were analysed. The patients, who had the surgery with the same non-constrained shoulder prosthesis by two senior surgeons and had post-operative computed tomography (CT) scans during the follow-up period, were included in this study. The patients with pathological fractures, associated fractures, early or late post-operative infection period, and under 2 years' follow-up period were excluded from the study. We analysed 25 patients matching these criteria, who were involved in the post-operative rehabilitation programme in Dokuz Eylül University Hospital. The study was conducted in accordance with the principles of the Declaration of Helsinki. (Ethical committee approval no: 2013/17-14)

Radiological evaluation; the lateral glenohumeral offset and humeral offset were measured on plain radiographs (Figure 1 and 2). The distance between the prosthesis surface and the acromion distal edge was measured on a coronal CT scan (Figure 3) (13). There were two parameters in the axial plane. Once medial malpositioning of both tuberosities was analysed, the bicipital groove was identified in the distal plane of the proximal humerus in the non-fractured area and followed proximally. Tuberosity placement was considered normal either when the bicipital groove could be followed in the axial plane from distal to proximal without a gap of $0.5 \mathrm{~cm}$ or more or when there was no medial overlapping of tuberosities in relation to the prosthetic head (Figure 4). Malpositioning was graded as less than $0.5 \mathrm{~cm}, 0.5$ to $1.0 \mathrm{~cm}$, and more than $1.0 \mathrm{~cm}$ (12). The second parameter on the axial plane was retroversion. The retroversion of the prosthesis could not be evaluated using epicondyles because our patients did not have distal humerus CT sections (Figure 5). The retroversion was accepted as normal if the anterior fin of the prosthesis was located anterior to the tuberculum minus or the bicipital groove was located $8 \pm 2 \mathrm{~mm}$ anterior to the lateral fin of the prosthesis (10). In 1994, Goutallier et al. (14) investigated fatty infiltration in rotator cuff tears by measuring on CT sections (Figure 6).They classified fatty infiltration in stages 0 to 4 . In this study, the classification of fatty infiltration in the supraspinatus muscle was performed by the radiology department, which was unaware of the post-operative clinics of the patients. CT scans and radiographs were evaluated by the agreement of two different observers.

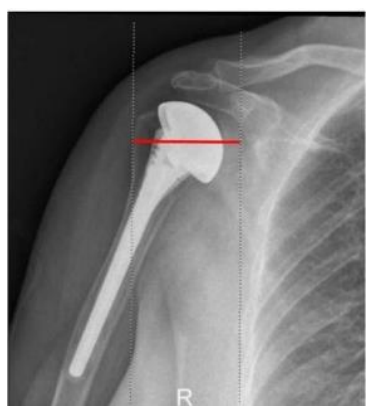

Figure 1. Radiologic evaluation of lateral glenohumeral offset.

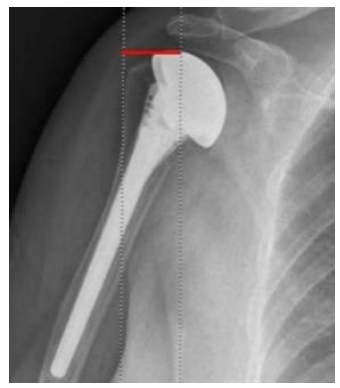

Figure 2. Measurement of the lateral humeral offset on shoulder AP graphy.

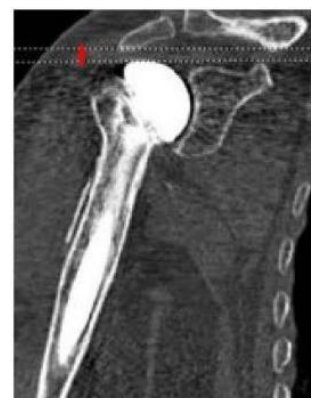

Figure 3. Subacromial gap on CT. 


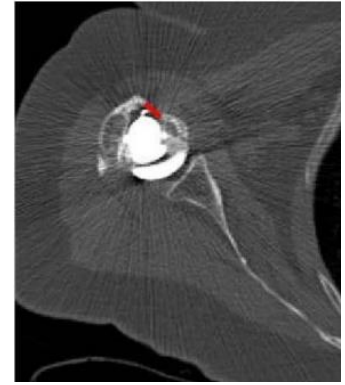

Figure 4. Malposition of tuberosities.

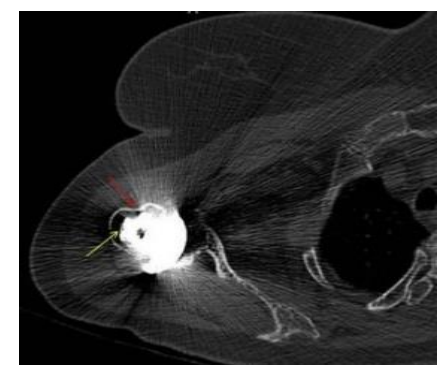

Figure 5. The relationship between bicipital groove (red arrow) and lateral fin of prosthesis (yellow arrow) demonstrates retroversion of humeral stem.

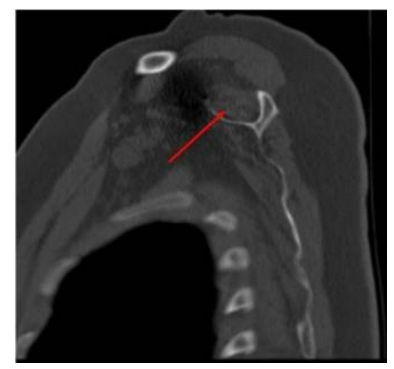

Figure 6. Stage II fatty degeneration of supraspinatus muscle on sagittal CT section.

Functional scoring; the patients were evaluated in terms of functional outcomes using the American Shoulder and Elbow Society (ASES) score, Constant-Murley score, and Disabilities of the Arm, Shoulder, and Hand (DASH) index score.

Statistical analyses; the SPSS 15.0 program was used to perform data analysis. Descriptive statistics of dependent and independent variables was made, and the frequency, percentage, mean, and standard deviation were calculated. The minimum and maximum values were also used as descriptive statistics.The Mann-Whitney U test and KruskalWallis test were used to perform non-parametric tests. The significance level was taken as less than $\mathrm{p}<0.05$. Since malpositioning and fatty degeneration parameters were divided into three groups, if the Kruskal-Wallis test was found to be significant in intergroup comparisons, the Mann-Whitney U test had to be applied to determine the difference between the groups. Therefore, after the KruskalWallis test, the Mann-Whitney $U$ test with the Bonferroni correction was performed.

\section{Results}

The mean follow-up period of 25 patients, who underwent hemiarthroplasty in the acute period after proximal humerus fractures, was 5 years (range, $3-$ 10 years). The mean age of the patients at the time of trauma was 68 years (range, 52-84 years). There were 19 women and 6 men. The right side was affected in 15 of the patients, and dominant arm was involved in seventeen of them. The fractures were categorized using the Neer classification system. The classification was established by pre-operative radiographs and CT scans (performed in 13 fractures). Thirteenof patients in the study were classified as Neer III and 12 of them were NeerIV.

The mean lateral glenohumeral offset was measured as $48.65 \mathrm{~mm}$ (range, $42.8-59.3 \mathrm{~mm}$ ). The mean lateral humeral offset was $23.22 \mathrm{~mm}$ (range, $14.8-34.0 \mathrm{~mm})$. To simplify the statistical evaluation, these parameters were examined in two groups as below and above of the mean values.

The average distance between the acromion tip and the prosthesis was $8.1 \mathrm{~mm}$ (range, 4.8-13.7 $\mathrm{mm}$ ). Six patients were found to be under $7.0 \mathrm{~mm}$.

Tuberculum malpositioning was evaluated in three groups: 14 patients in the first group determined as 0 to $5 \mathrm{~mm}, 6$ patients in the second group as 5 to $10 \mathrm{~mm}$, and 5 patients in the third group as 10 to $15 \mathrm{~mm}$.

On axial CT scans, there were 18 patients with normal retroversion, and seven prostheses were evaluated as being retroverted.

When fatty degeneration was examined in the supraspinatus muscle, four patients had Goutallier stage 0,16 Goutallier stage 1 , and 5 Goutallier stage 2 fatty degeneration. None of the patients had stage 3 and 4 fatty degeneration (Table 1).

In terms of the functional performance of the shoulder, the mean forward flexion was measured as 99 degrees (range, 50-140 degrees). The mean abduction was 92 degrees (range, 70-120degrees). It was observed that the thumb reached the thoracic vertebral level in eight patients with active internal rotation. Three patients were at L5 vertebral level and one patient at the gluteal level. The mean Constant-Murley score of 25 patients was calculated to be 66 (range, 41-88). One patient was excellent, three were evaluated as good, five were moderate, and sixteen were poor. In the ASES evaluation, the mean score of 25 patients was 70 (range, 48-88). The mean DASH index score was measured as 23 (range, 46-11; Table 2).

Higher Constant-Murley and ASES scores and higher degrees of abduction and forward flexion were found to be associated with values higher than $50 \mathrm{~mm}$ of the lateral glenohumeral offset $(\mathrm{p}=0.106$, $0.079,0.055$ and 0.301 respectively). A low DASH index score was found to be statistically significant in cases with $50 \mathrm{~mm}$ and higher values of the lateral glenohumeral offset $(\mathrm{p}=0.017)$. 
Table 1. Radiologicparameters of 25 shoulders.

\begin{tabular}{|c|c|c|c|c|c|c|c|}
\hline Patient & $\begin{array}{c}\text { Fracture } \\
\text { Type } \\
\text { Neer }\end{array}$ & $\begin{array}{l}\text { Lat. Ghumeral } \\
\text { Offset } \\
(\mathrm{mm})\end{array}$ & $\begin{array}{c}\text { Lat. Humeral } \\
\text { Offset } \\
(\mathrm{mm})\end{array}$ & $\begin{array}{c}\text { Subacromial } \\
\text { Gap } \\
(\mathrm{mm})\end{array}$ & $\begin{array}{l}\text { Malposition } \\
\quad(\mathrm{mm})\end{array}$ & Retroversion & $\begin{array}{c}\text { Fatty } \\
\text { Degeneration } \\
\text { Goutallier }\end{array}$ \\
\hline 1 & 4 & 54 & 27 & 6.70 & 6.7 & $\mathrm{~N}$ & 0 \\
\hline 3 & 3 & 50.8 & 25.1 & 13.6 & 8.1 & $\mathrm{~N}$ & 1 \\
\hline 4 & 4 & 42.8 & 14.8 & 7.4 & 3.7 & $\mathrm{~N}$ & 1 \\
\hline 5 & 3 & 52.3 & 27.4 & 9.3 & 15.3 & Retroverted & 1 \\
\hline 8 & 4 & 51.5 & 25.4 & 5.1 & 3.3 & $\mathrm{~N}$ & 0 \\
\hline 9 & 3 & 43 & 16.9 & 8.9 & 16.7 & Retroverted & 1 \\
\hline 10 & 4 & 53.9 & 25 & 7.6 & 8.2 & $\mathrm{~N}$ & 1 \\
\hline 11 & 3 & 47.1 & 18.4 & 7.1 & 3.1 & 1 & 2 \\
\hline 12 & 4 & 46.6 & 21.3 & 5.8 & 3.1 & 1 & 1 \\
\hline 17 & 3 & 50.9 & 24.4 & 5.9 & 10.2 & $\mathrm{~N}$ & 1 \\
\hline 18 & 4 & 44.1 & 20 & 7.9 & 2.3 & $\mathrm{~N}$ & 0 \\
\hline 19 & 3 & 45.3 & 17.4 & 7.1 & 3.9 & Retroverted & 1 \\
\hline 20 & 3 & 42.8 & 22.7 & 7.2 & 2.2 & $\mathrm{~N}$ & 2 \\
\hline 21 & 3 & 56.6 & 24 & 7.2 & 2.4 & $\mathrm{~N}$ & 2 \\
\hline 22 & 3 & 45.3 & 26.4 & 5.2 & 3.1 & $\mathrm{~N}$ & 1 \\
\hline 23 & 3 & 42.8 & 25.2 & 13.7 & 7.9 & $\mathrm{~N}$ & 1 \\
\hline 24 & 4 & 52.4 & 15 & 7.5 & 3.5 & $\mathrm{~N}$ & 1 \\
\hline 25 & 3 & 45.9 & 27.5 & 9.4 & 15 & Retroverted & 1 \\
\hline
\end{tabular}

Table 2. Fuctional evaluation of 25 shoulders.

\begin{tabular}{|c|c|c|c|c|c|c|c|c|}
\hline Patient & $\begin{array}{c}\text { Fracture } \\
\text { Type } \\
\text { Neer }\end{array}$ & $\begin{array}{c}\text { Fatty } \\
\text { Degeneration } \\
\text { Goutallier }\end{array}$ & $\begin{array}{l}\text { Constant- } \\
\text { Murley }\end{array}$ & ASES & DASH & $\begin{array}{l}\text { Forward } \\
\text { Elevation } \\
\quad\left({ }^{\circ}\right)\end{array}$ & $\begin{array}{c}\text { Abduction } \\
\left({ }^{\circ}\right)\end{array}$ & $\begin{array}{l}\text { Internal } \\
\text { Rotation } \\
\quad\left(^{\circ}\right)\end{array}$ \\
\hline 1 & 4 & 1 & 82 & 84 & 13 & 110 & 95 & $\mathrm{~T} 11$ \\
\hline 2 & 4 & 2 & 64 & 68 & 18 & 90 & 90 & $\mathrm{~L} 2$ \\
\hline 3 & 3 & 2 & 70 & 74 & 13 & 100 & 95 & $\mathrm{~T} 12$ \\
\hline 4 & 4 & 2 & 72 & 76 & 14 & 95 & 90 & L1 \\
\hline 5 & 3 & 2 & 77 & 72 & 14 & 110 & 90 & L1 \\
\hline 6 & 4 & 3 & 44 & 52 & 44 & 80 & 70 & L5 \\
\hline 7 & 3 & 2 & 68 & 74 & 16 & 85 & 90 & L2 \\
\hline 8 & 4 & 1 & 82 & 86 & 11 & 140 & 110 & $\mathrm{~T} 5$ \\
\hline 9 & 3 & 2 & 62 & 66 & 40 & 90 & 90 & L1 \\
\hline 10 & 4 & 2 & 90 & 82 & 14 & 120 & 110 & $\mathrm{~T} 12$ \\
\hline 11 & 3 & 3 & 77 & 82 & 15 & 110 & 95 & $\mathrm{~T} 12$ \\
\hline 12 & 4 & 2 & 61 & 54 & 34 & 90 & 80 & $\mathrm{~L} 4$ \\
\hline 13 & 4 & 3 & 41 & 48 & 46 & 50 & 80 & Gluteal \\
\hline 14 & 3 & 2 & 74 & 78 & 15 & 90 & 90 & L1 \\
\hline 15 & 4 & 1 & 66 & 72 & 22 & 120 & 90 & L1 \\
\hline 16 & 4 & 2 & 48 & 54 & 30 & 90 & 95 & $\mathrm{~L} 1$ \\
\hline 17 & 3 & 2 & 85 & 88 & 13 & 110 & 105 & $\mathrm{~T} 12$ \\
\hline 18 & 4 & 1 & 87 & 86 & 14 & 140 & 120 & T12 \\
\hline 19 & 3 & 2 & 51 & 58 & 43 & 90 & 85 & L5 \\
\hline 20 & 3 & 3 & 53 & 62 & 30 & 100 & 80 & L3 \\
\hline 21 & 3 & 3 & 45 & 62 & 35 & 90 & 100 & L3 \\
\hline 22 & 3 & 2 & 69 & 70 & 22 & 120 & 110 & $\mathrm{~T} 12$ \\
\hline 23 & 3 & 2 & 70 & 74 & 15 & 90 & 95 & L2 \\
\hline 24 & 4 & 2 & 74 & 82 & 16 & 100 & 85 & L2 \\
\hline 25 & 3 & 2 & 46 & 52 & 40 & 75 & 70 & L5 \\
\hline
\end{tabular}


Table 3. The effect of malpositon of tubercules as ASSES, DASH, Anterior flexion, Abduction and Constant-Murley score.

\begin{tabular}{lcccccccc}
\hline & $\mathbf{0 - 5} \mathbf{~ m m * *}$ & $\mathbf{5 - 1 0} \mathbf{~ m m}$ & $\mathbf{1 0 - 1 5} \mathbf{~ m m}^{* *}$ & Total & Median & Min & Max & $\boldsymbol{p}^{* *}$ \\
\hline ASSES & 13 & 7 & 5 & 25 & 72 & 48 & 88 & $\mathbf{. 0 0 1}$ \\
DASH & 13 & 7 & 5 & 25 & 16 & 11 & 46 \\
Anterior Flexion & 13 & 7 & 5 & 25 & 95 & 50 & 140 \\
Abduction & 13 & 7 & 5 & 25 & 90 & 70 & 120 & $\mathbf{. 0 0 3}$ \\
Constant- Murley Score & 13 & 7 & 5 & 25 & 69 & 41 & 90 \\
\hline *Kruskal Wallis Test **Man Whitney u test was applied between binary variables. ***Pairwise comparisons of malposition adjusted p values: 3-2:.222; 3-1:.004; 2-1:535
\end{tabular}

Table 4. Grade of fatty degeneration affects functional outcome.

\begin{tabular}{|c|c|c|c|c|c|c|c|c|}
\hline & & $\mathbf{N}$ & & & & & & \\
\hline & Grade 0** & Grade 1 & Grade 2** & Total & Median & Min & Max & $p^{*}$ \\
\hline ASSES & 4 & 16 & 5 & 25 & 72 & 48 & 88 & .036 \\
\hline DASH & 4 & 16 & 5 & 25 & 16 & 11 & 46 & .032 \\
\hline Anterior Flexion & 4 & 16 & 5 & 25 & 95 & 50 & 140 & .014 \\
\hline Abduction & 4 & 16 & 5 & 25 & 90 & 70 & 120 & .129 \\
\hline Constant-Murley Score & 4 & 16 & 5 & 25 & 69 & 41 & 90 & .029 \\
\hline
\end{tabular}

Better ASES and Constant-Murley scores and higher degrees of forward flexion were seen with values greater than $23 \mathrm{~mm}$ of the lateral humeral offset $(p=0.467,0.317$ and 0.317 respectively). Higher internal rotation range and lower DASH index scores were seen at $23 \mathrm{~mm}$ and higher values of the lateral humeral offset $(\mathrm{p}=0.081$ and 0.075 respectively). At this range of the lateral humeral offset, the presence of a higher range of abduction was statistically significant $(\mathrm{p}=0.021)$.

In cases, where subacromial distances were longer than $7 \mathrm{~mm}$, higher Constant-Murley and ASES scores and lower DASH index scores were found. Better degrees of forward flexion and abduction were seen to be associated with the values of subacromial distance greater than $7 \mathrm{~mm}(\mathrm{p}=0.303$ and 0.475 respectively).

In 18 patients with normal retroversion, higher Constant-Murley and ASES scores and lower DASH index scores were found to be statistically significant $\quad(p=0.037, \quad 0.014$ and 0.027 respectively).Also, in patients with normal retroverted prostheses, it was statistically significant to have a more range of motion in forward flexion. $(\mathrm{p}=0.013)$

When tuberculum malpositioning was examined on axial CT sections, in the first group of 0 to $5 \mathrm{~mm}$ malpositioning, higher Constant-Murley, ASES scores, lower DASH index scores, and better range of motion in forward flexion, internal rotation and abduction were found to be statistically significant $(\mathrm{p}=0.001,0.001,0,003,0.006,0.037$ and 0.043 respectively), using the Kruskal-Wallis test (Table 3). The Bonferroni-corrected Mann-Whitney U test was applied to determine which parameters could be the source of this significance. Between the first and third groups, there were statistically significant differences in terms of the Constant-Murley, ASES, DASH, Anteriorflexion, andabductionindex scores $(\mathrm{p}=0.001, \quad 0.001, \quad 0.003, \quad 0.006$ and 0.043 respectively).
The patients, who were evaluated as stage 0 fatty degeneration in the supraspinatus muscle, had higher Constant-Murley, ASES scores, lower DASH index scores, and greater range of motion in forward flexion, abduction, and internal rotation, using the Kruskal-Wallis test ( $\mathrm{p}=0.029,0.036,0.032,0.014$, 0129 and 0.029 respectively) (Table 4 ).

\section{Discussion}

Shoulder hemiarthroplasty is a technically difficult procedure for restoring the functional capacity of the shoulder joint in four- and three-part humerus fractures, fracture dislocations, and impaction fractures involving more than $50 \%$ of the joint surface (16-17). The success of hemiarthroplasty depends on the appropriate selection of patients (fracture type), post-operative rehabilitation, and surgical technique. The correct surgical technique requires optimal prosthesis height, appropriate retroversion, secure fixation of tuberosities, and optimal soft-tissue balance, with a significant contribution of the rotator cuff muscles $(18,19)$. Anatomical tubercle reconstruction is critical for the proper balance of the rotator cuff muscles.

According to previous anatomical studies, the prosthetic retroversion was considered normal, as it was between 0 and 40 degrees in relation to the transepicondylar line. Boileau et al. (20) stated that it may be difficult to provide appropriate retroversion even in the hands of experienced surgeons. They confirmed that the most common error was excessive retroverted placement of the humeral component. The retroverted prosthesis affects the placement of the tuberculum majus in the horizontal plane. The replacement of the tuberculum majus in retroverted implanted prostheses is possible when the arm is in external rotation. This leads to the pull-out of sutures when the arm is neutrally rotated. When the arm is internally rotated, the tuberculum majus migrates posteriorly (20). In addition, 
excessive retroversion may lead to posterior subluxation of the prosthesis (21). In this study, normal retroverted shoulders had better functional scores. Retroversion affects functional outcomes, as it is related to the position of the tuberculum majus in the horizontal plane.

The importance of the lateral glenohumeral offset for shoulder function lies in the relationship between the moment arm of the deltoid muscle, the length of the rotator cuff muscles at rest, and capsule tension. Iannotti et al. (22) reported that the lateral glenohumeral offset provided insights into the size of the humeral head. A range of 54 to $58 \mathrm{~mm}$ is considered optimal for the glenohumeral offset. In this study, higher functional values were present with $50 \mathrm{~mm}$ and higher values of the glenohumeral offset, which was not statistically significant. Demirhan (13) stated that when all radiological parameters were examined, only the lateral humeral offset was related to the result in hemiarthroplasty. He suggested that the degree of anterior elevation increased in correlation with the lateral humeral offset (13). Rietveld et al. (23) reported that the lateral humeral offset is associated with the degree of glenohumeral abduction, and this distance forms the moment arm of the supraspinatus with deltoid muscle. It was found statistically significant that a higher range of glenohumeral abduction was present when the lateral humeral offset was greater than 23 $\mathrm{mm}(\mathrm{p}<0.05)$. We believe that the higher lateral humeral offset increases the amount of abduction by extending the moment arm of the deltoid and supraspinatus muscles.

The subacromial space is defined as the distance between the surface of the prosthetic head and the line of sclerosis of the acromion. The measurement of the subacromial space after hemiarthroplasty may give an idea about superior migration of the prosthesis. In an anatomical study, Iannotti et al. (24) stated that $7 \mathrm{~mm}$ or lower values of the subacromial distance indicate superior migration of the prosthesis. Superior migration of the prosthesis adversely affects functional outcomes. Nonanatomical tubercle reconstruction may also lead to superior migration of the prosthesis (25). In our study, the mean subacromial distance was $8.1 \mathrm{~mm}$. It was seen that there was no statistically significant relationship between the subacromial gap and the intermediate-term functional scores. In some studies, because it is less dependent on a technique of radiological evaluation, measurements using Gothic arch give clearer information about migration of the prosthesis (26). The mismatch between the subacromial space and the functional scores may be related to both the inadequacy of the number of patients and the possible errors in measurement because of not using the Gothic arch method.

Tuberosity malpositioning occurs due to ineffective fixation in relation to low bone quality and rupture of the suture or non-anatomical location of the other tubercle. Greiner et al. (12) showed that best functional scores are found in cases where the displacement of tubercles is about 0 to $5 \mathrm{~mm}$. Poor clinical results were seen in cases where the displacement was more than $1 \mathrm{~cm}$.In a retrospective study, Kralingeret al. (9) evaluated anatomical repositioning of tubercles as the only factor that significantly affected the surgical outcome with the use of the Constant-Murley scoring system. Although the frequency of persistent pain with anatomical tuberculum union is low in the late postoperative period, there could be shoulder limitation that may be equivalent to ankylosis with complete anatomical tuberculum union. This shows that the anatomical tuberculum union is only part of the success (9). In this study, the first group - with malpositioning determined as 0 to $5 \mathrm{~mm}$ - had higher Constant-Murley and ASES scores and lower DASH index scores, and there was a statistically significant difference in forward flexion and abduction and a wider range of motion in internal rotation $(\mathrm{p}<0.05)$.

Reuther et al. (27) determined the mean Constant-Murley score of 57 patients as 50.0. Kralinger et al. (9) reported a mean constant score of their series with 167 patients as 55.4. Movin et al. (28) reported the mean constant score as 38 in their series with 28 patients. In this study, the ConstantMurley score of 25 patients was 66. Scores after shoulder arthroplasty are so diverse in the literature that other parameters have been examined to explain this situation. Fatty degeneration is one of them. There is a tendency to get worse clinical results as the amount of fatty degeneration increases. However, there is a direct correlation between tuberculum malpositioning and amount of fatty infiltration. The other factors of fatty infiltration may also include the effects of trauma, surgery-related denervation, and decreased range of motion of the shoulder joint (12). In this study, the patients whose fatty infiltration in the supraspinatus muscle evaluated as stage 0 according to the Goutillier classification were found to have higher ConstantMurley and ASES scores and lower DASH index scores and had a tendency to have more range of motion in forward flexion, abduction, and internal rotation $(\mathrm{p}<0.05)$. However, this condition may be caused by the effects of trauma, surgery-induced denervation, and decreased range of motion, as well as fatty degeneration secondary to tuberculum malpositioning. Compared to the current literature, we did not find a direct relationship between tuberculum malpositioning and fatty degeneration. The pre-operative evaluation of fatty degeneration may be needed in terms of the choice of prosthesis, such as reverse shoulder arthroplasty. In a metaanalysis, Du et al. (29) confirmed that reverse shoulder arthroplasty has become a beneficial choice in the treatment of displaced three- or four-part fractures in elderly patients, which might result in 
more favorable clinical outcomes. Gallineta et al. (30) also confirmed that, compared to hemiarthroplasty, reverse shoulder arthroplasty provides a more reproducible function with better recovery of active forward flexion and abduction even when tuberosities are not reattached or do not heal properly. However, reverse shoulder arthroplasty has many complications, which is not the subject of this study (31).

This retrospective study has some limitations. There is inadequate patient population because of the exclusion criteria to get more homogeneous group. The functional condition of the shoulder before fracture and pre-operative evaluation of fatty infiltration may be more valuable when making a comparison.

In conclusion; achieving success in hemiarthroplasty for acute proximal humerus fractures is difficult. The anatomical final position of the tubercle and the appropriate values of the humeral offset were found to be correlated with more successful functional results, as defined in the literature. The effect of fatty degeneration should be taken into consideration, and the surgical technique should be reviewed when fatty degeneration is detected before surgery.

Ethics Committee Approval: Ethical Board of Dokuz Eylül University was obtained with the letter dated 09.05.2013 and numbered 2013/17-14.

\section{References}

1. Fenichel I, Oran A, Burstein G, Perry M. Percutaneous pinning using threaded pins as a treatment option for unstable two and three part fractures of a proximal humerus: A retrospective study. Int Orthop. 2006;30(3):153-7.

2. Misra A, Kapur R, Maffulli N. Complex proximal humeral fractures in adults: A systematic review of management. Injury. 2001;32:363-72.

3. Court-Brown CM, Caesar B. Epidemiology of adult fractures: A review. Injury. 2006;37(8):691-7.

4. Lanting B, MacDermid J, Drosdowech D, Faber KJ. Proximal humeral fractures: A systematic review of treatment modalities. J Shoulder Elbow Surg. 2008;17(1):42-54.

5. Moen TC, Bigliani LU. Hemiarthroplasty for four-part fractures of the proximal humerus. Oper Tech Orthop. 2011;21:94-100.

6. Robinson CM, Page RS, Hill RM, Sanders DL, Court-Brown CM, Wakefield AE. Primary hemiarthroplasty for treatment of proximal humeral fractures. J Bone Joint Surg Am. 2003;85(7):1215-23.

7. Huffman GR, Itamura JM, McGarry MH, Gililland J, Lee TQ. Neer Award 2006: Biomechanical assessment of inferior tuberosity placement during hemiarthroplasty for four-part proximal humeral fractures. J Shoulder Elbow Surg. 2008;17(2):189-96.

8. Hempfing A, Leunig M, Ballmer FT, Hertel R. Surgical landmarks to determine humeral head retrotorsion for hemiarthroplasty in fractures. J Shoulder Elbow Surg. 2001;10:460-3.

9. Kralinger F, Schwaiger R, Wambacher M, et al. Outcome after primary hemiarthroplasty for fracture of the head of the humerus. A retrospective multicentre study of 167 patients. J Bone Joint Surg Br. 2004;86:217-9.

10. Frankle MA, Greenwald DP, Markee BA, Ondrovic LE, Lee WE III. Biomechanical effects of malposition of tuberosity fragments on the humeral prosthetic reconstruction for four- part proximal humerus fractures. J Shoulder Elbow Surg. 2001;10:321-6.

11. Gerber C, Yian EH, Pfirrmann CA, Zumstein MA, Werner CM. Subscapularis muscle function and structure after total shoulder replacement with lesser tuberosity osteotomy and repair. J Bone Joint Surg Am. 2005;87:1739-45.

12. Greiner SH, Diederichs G, Kroning I, Scheibel M, Perka C. Tuberosity position correlates with fatty infiltration of the rotator cuff after hemiarthroplasty for proximal humeral fractures. J Shoulder Elbow Surg. 2009;18(3):431-6.

13. Demirhan M. Factors affecting the results of hemiarthroplasty for proximal humerus fractures. Acta Orthop Traumatol Turc. 2000;34:463-74.

14. Goutallier D, Postel JM, Bernageau J, Lavau L. Fatty muscle degeneration in cuff ruptures pre and postoperative evaluation by CT scan. Clin Orthop Relat Res. 1994;304:7883.

15. Torrens C, Corrales M, Melendo E, Solano A, RodríguezBaeza A, Cáceres E. The pectoralis major tendon as a reference for restoring humeral length and retroversion with hemiarthroplasty for fracture. J Shoulder Elbow Surg. 2008;17(6):947-50.

16. Bigliani LU, McCluskey GM III. Prosthetic replacement in acute fractures of the proximal humerus. Semin Arthroplasty .1990;1(2):129-37.

17. Solberg BD, Moon CN, Franco DP, Paiement GD. Surgical treatment of three and four-part proximal humeral fractures. J Bone Joint Surg A. 2009;91(7):1689-97.

18. Bigliani LU. Proximal humeral arthroplasty for acute fractures. In: Craig EV, ed. Master Techniques in Orthopaedic Surgery: The Shoulder. 1995; 259-74. New York: Raven Press.

19. Zukerman J, Cuomo F, Koval K. Proximal humeral replacement for complex fractures, indications, and surgical technique. Instr Course Lect. 1997;64:7-14.

20. Boileau S, Krishnan SG, Tinsi L, Walch G, Coste JS, Molé D. Tuberosity malposition and migration: Reasons for poor outcomes after hemiarthroplasty for displaced fractures of the proximal humerus. J Shoulder Elbow Surg. 2002;11(5):40112.

21. Gürbüz H, Sekhavat H, Demiral H. Our results of shoulder prosthesis. Acta Orthop Traumatol Turc. 2004;32(2):100-2.

22. Frankle MA, Mighell MA. Techniques and principles of tuberosity fixation for proximal humeral fractures treated with hemiarthroplasty. J Shoulder Elbow Surg. 2004;13(2):239-47.

23. Rietveld AB, Daanen HA, Rozing PM, Obermann WR. The lever arm in glenohumeral abduction after hemiarthroplasty. J Bone Joint Surg Br. 1988;70:561-5.

24. Iannotti JP, Gabriel JP, Schneck SL, Evans BG, Misra S. The normal glenohumeral relationships. An anatomical study of one hundred and forty shoulders. J Bone Joint Surg Am. 1992;74(4):491-500.

25. Young AA, Walch G, Pape G, Gohlke F, Favard L. Secondary rotator cuff dysfunction following total shoulder arthroplasty for primary glenohumeral osteoarthritis: Results of a multicenter study with more than five years of followup. J Bone Joint Surg. 2012;94(8):685-93.

26. Gracitelli MEC, Duarte FA, Toffoli RP, Burnato JH. Shoulder arthroplasty in osteoarthritis: Correlation between function and radiographic parameters. Acta Ortop Bras. 2013;21(2):98-102.

27. Reuther F, Muller S, Wahl D. Management of humeral head fractures with a trauma shoulder prosthesis: Correlation between joint function and healing of the tuberosities. Acta Orthop Belg. 2007;73:179-87.

28. Movin T, Sjoden GO, Ahrengart L. Poor function after shoulder replacement in fracture patients. A retrospective evaluation of 29 patients followed for 2-12 years. Acta Orthop Scand. 1998;69:392-6.

29. Du S, Ye J, Chen H, Li X, Lin Q. Interventions for treating 3 or 4-part proximal humeral fractures in elderly patient: A network meta-analysis of randomized controlled trials. Int $\mathbf{J}$ Surg. 2017;48:240-6.

30. David G, Xavier O, Lauryl D , Choukry D, Philippe V , Pascal B , et al.Is reverse total shoulder arthroplasty more 
effective than hemiarthroplasty for treating displaced proximal humerus fractures in older adults? A systematic review and meta-analysis. Orthop Traumatol Surg Res. 2018;104:759-66.
31. Barco R, Savvidou OD,Sperling JW, Sanchez-Sotelo J, Cofield RH. Complications in reverse shoulder arthroplasty. EFORT Open Rev. 2016;1(3):72-80. 